\title{
Gene expression profiling identifies Fibronectin I and CXCL9 as candidate biomarkers for breast cancer screening
}

\author{
E Ruiz-Garcia', V Scott', C Machavoine ${ }^{2}$, JM Bidart ${ }^{2}$, L Lacroix ${ }^{2}$, S Delaloge ${ }^{1,3}$ and F Andre, ${ }^{*, 1,3}$ \\ 'Breast Cancer Translational Research Unit, UPRES EA03535, Université Paris XI, Institut Gustave Roussy, Villejuif, France; ${ }^{2}$ Department of Laboratory \\ Medicine, Institut Gustave Roussy, Villejuif, France; ${ }^{3}$ Breast Cancer Unit, Department of Medicine, Institut Gustave Roussy, Villejuif, France
}

\begin{abstract}
BACKGROUND: There is a need to develop blood-based bioassays for breast cancer (BC) screening. In this study, differential gene expression between BC samples and benign tumours was used to identify candidate biomarkers for blood-based screening. METHODS: We identified two proteins (Fibronectin I and CXCL9) from a gene expression data set that included I 20 BC samples and 45 benign lesions. These proteins fulfil the following criteria: differential gene expression between cancer and benign lesion, protein released in the extracellular medium and stable in the serum, commercially available ELISA kit, ELISA accuracy in a feasibility study. Protein concentrations were determined by ELISA. Blood samples were from normal volunteers $(n=119)$ and early BC patients $(n=133)$.

RESULTS: Seventy-three per cent of patients had CTI-T2 tumour. Patients had higher CXCL9 and Fibronectin I concentrations than volunteers. CXCL9 mean concentration was $85 \mathrm{I}$ and $635 \mathrm{pg} \mathrm{ml}^{-1}$ for patients and volunteers respectively $(P=0.013)$. CXCL9 concentration was significantly higher in patients with estrogen receptor (ER)-negative compared with volunteers $(P=0.003)$, data consistent with gene expression profile. Fibronectin I mean concentration was $190 \mu \mathrm{g} \mathrm{ml}^{-1}$ for patients and $|25 \mu \mathrm{gml}|^{-1}$ for volunteers $(P<0.001)$. Areas under the curve for BC diagnosis were 0.78 and 0.62 for Fibronectin I and CXCL9 respectively. A combined score including Fibronectin I and CXCL9 dosages presented $53 \%$ of sensitivity and $98 \%$ of specificity. Similar performances were observed for ER-negative tumours.

CONCLUSIONS: This study suggests that Fibronectin I/CXCL9 dosage in serum could screen a significant rate of BC, including ER-negative, and that differential gene expression analysis is a good approach to select candidate biomarkers to set up blood assays cancer screening.

British Journal of Cancer (2010) I 02, 462-468. doi:10.1038/sj.bjc.66055 I I www.bjcancer.com
\end{abstract}

Published online 12 January 2010

(c) 2010 Cancer Research UK

Keywords: breast cancer; DNA arrays; screening; biomaker

Breast cancer $(\mathrm{BC})$ is the most frequent cancer in women. World estimation is 850000 new cases per year with 340000 deaths per year. In 2005, France had reported 49814 new cases. Although several advances (mammogram screening and post-operative treatments) have allowed improvements in 5-year survival in this disease, more than 11000 women died of BC in France (La situation du cancer en France). Breast cancer incidence in the European population in 2006 was $29 \%$, with a mortality rate of $18 \%$ (Karim-Kos et al, 2008). Early diagnosis could decrease BC mortality by means of cancer downstaging. As an illustration, randomised studies have shown that mammogram screening decreases the BC death rates by $21 \%$ (Nystrom et al, 2002). Although mammogram screening has allowed an undisputable benefit, it has several limitations. First, it is associated with a significant rate of false-positive results, leading to unnecessary biopsies or surgeries (Fletcher and Elmore, 2003; Delaloge et al,

* Correspondence: Dr F Andre, Breast Cancer Unit, Department of Medicine, Institut Gustave Roussy, 39 rue C Desmoulins, 94805 Villejuif, France; E-mail: fandre@igr.fr

Received 9 September 2009; revised 21 November 2009; accepted 29 November 2009; published online 12 January 2010
2005). Second, this technology mainly detects slowly proliferating tumours that occur after the age of 50 years, but exhibits poor performance to screen aggressive tumours, especially in young women in whom breast density is high. Finally, although mass screening by mammogram has been well implemented in most of the European countries, $20 \%$ of the population are still not compliant with it (Hakama et al, 2008). These patients usually present poor income and are excluded from this medical advance. Based on the observation that a mammogram offers a significant, but suboptimal, screening for $\mathrm{BC}$, new approaches have been tested to improve $\mathrm{BC}$ detection. New radiological technologies have been tested in this setting. MRI has been shown to detect most of the cancers early, including those in younger women, but this approach is limited by a high rate of false-positive results, together with a high cost. Ultrasonography, combined with a mammogram, also increases the likelihood of $\mathrm{BC}$ detection, but is once again associated with high rate of false positivity.

Until now, no serum biomarker has been shown to allow an early diagnosis of BC. As a consequence, current ASCO guidelines do not recommend the use of serum biomarker (CA15-3, CEA) for BC screening (Harris et al, 2007).

These data point out the need to develop new easy-to-do tests that would improve $\mathrm{BC}$ detection and decrease the rate of 
false-positive results associated with radiological examinations. In this study, we aimed at generating a blood-based assay that could screen BC. To achieve this goal, we first identified genes overexpressed in $\mathrm{BC}$ compared with benign lesions. We then determined which of these genes encoded for proteins released in the extracellular medium. Finally, we performed dosage of these proteins in the blood of overall $252 \mathrm{BC}$ or normal volunteers to determine whether these proteins were more concentrated in patients with $\mathrm{BC}$.

\section{PATIENTS AND METHODS}

\section{Identification of candidate proteins for breast cancer screening}

To identify which genes were overexpressed in BC, we used a public data set of exon arrays (Andre et al, 2009). This data set includes $120 \mathrm{BC}$ and 45 benign lesions. Samples were obtained by fine needle aspiration of breast lesions. Gene expression levels were determined as previously reported. The strategy used to select candidate biomarkers for blood-based screening is reported in Figure 1A. Genes overexpressed in BC ( $>2$-fold increase and FDR $<0.05)$ that encode for a protein released in the extracellular medium were selected for further analyses. To determine which genes encoded for a protein released in extracellular medium, we looked at the protein location in UniProt Knowledgebase (UniProtKB) section Swiss-Prot, to obtain functional information on proteins (http://www.uniprot.org/). Nevertheless, other methods of protein identification could be used. For example, we could use a difference between including Signal P and TMHMM databases. Signal P ((http://www.cbs.dtu.dk/services/SignalP/)) and TMHMM ((http://www.cbs.dtu.dk/services/TMHMM/) recognise signal peptides at the $\mathrm{N}$-terminal and transmembrane regions respectively. Proteins predicted by Signal P but not TMHMM could be secreted in the serum, and therefore represent a potential target for ELISA.

Of the proteins released in extracellular medium, we only kept for further analyses those for which an ELISA could be set up using commercially available antibodies. This approach allowed us to identify five candidate proteins (Fibronectin 1, CXCL9, CEACAM5, CHTRC1 and Complement factor B). Of these five, Complement Factor B (CFB) will no longer be considered, as the protein is unstable in serum.

\section{Patient selection}

Concentrations of candidate biomarkers were assessed in serum samples from 133 women with breast adenocarcinoma and 119 healthy women. Breast cancer patients were retrospectively selected to have presented a primary BC without metastases at diagnosis between 1999 and 2006. Blood samples were obtained at the time of diagnosis. Normal volunteers were healthy blood donors. They presented neither fever, nor cancer history, nor chronic infectious disease (HCV, HBV, HIV) history. As normal volunteers were aged between 18 and 62 years, we focused the analysis of samples from cancer patients in women aged between 18 and 60 years.
A

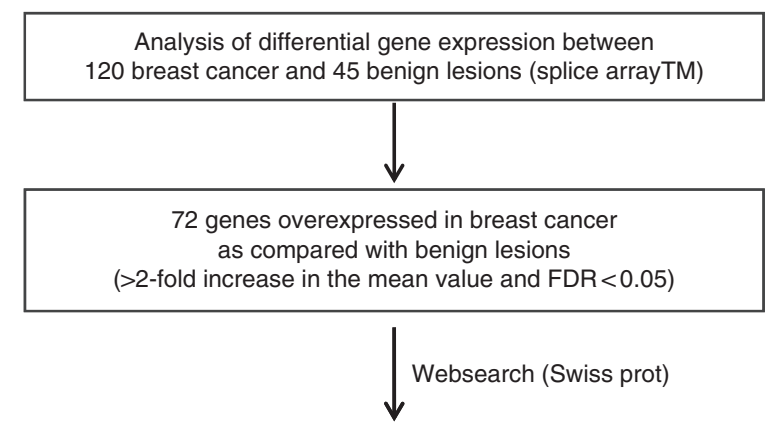

5 proteins met the following criteria: encoded by one of these 72 genes and for which an ELISA assay could be set up with commercially available $\mathrm{Ab}$

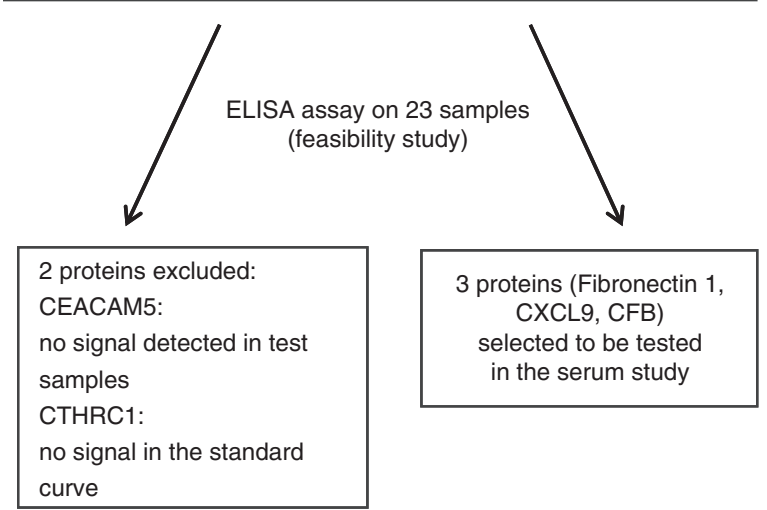

B
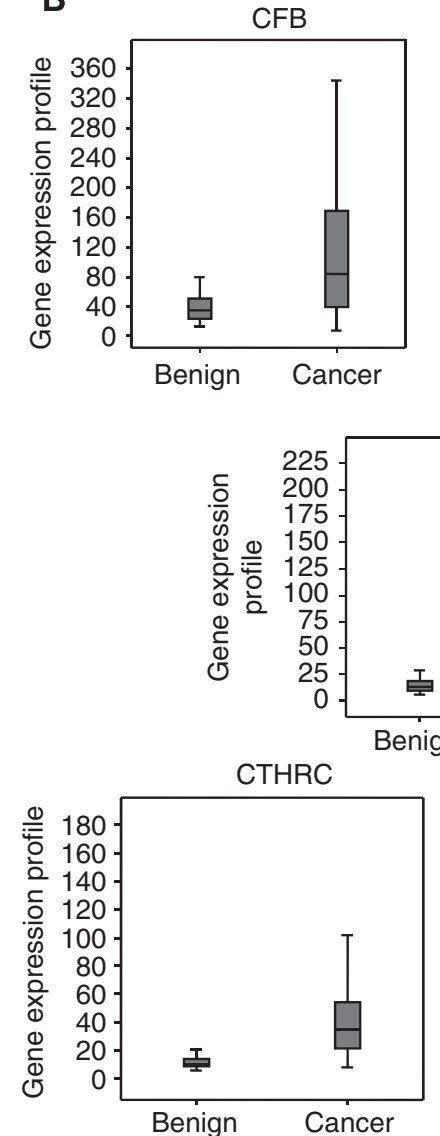

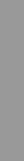
. 


\section{Sample processing}

Archived serum specimens were obtained from the Biological Resource Center of Gustave Roussy Institute. All samples have consent in accordance with approval granted by the ethics committee of the medical centre. Control sera were obtained in 2008 with a signed informed consent from normal volunteers of the French Blood Institution. All samples were centrifuged and aliquoted after collection and stored at $-80^{\circ} \mathrm{C}$ until the assays were performed. No repeat freezing or thawing was permitted.

\section{ELISA}

Three proteins were measured with commercially available enzyme immunoassay kits. Human MIG ELISA set BD OptEIA (Ref. 550998; BD Biosciences-Pharmingen, Franklin Lakes, NJ, USA) was used to determine CXCL9 concentration. Fibronectin 1 was measured with Human Fibronectin ELISA BMS2028 (Bender MedSystems, San Diego, CA, USA). Carcinoembryonic antigen-related cell adhesion molecule 5 (CEACAM5) concentrations were assessed using Carcinoembryonic Antigen Enzyme Immunoassay Test Kit (catalog no. 07BC-1011; MP Biomedicals, Solon, OH, USA). All the measurements were performed following the manufacturer's instructions.

As no ELISA was commercially available for CHTRC1, the ELISAs were set up in house (not shown). Nevertheless, positive controls were not detected for CHTRC1. This latter biomarker was not further explored in this study.

Absorbance was read at $450 \mathrm{~nm}$ using a spectrophotometer (ELx808; Fisher Bioblock Scientific, Pittsburgh, PA, USA). Sera concentration of each protein was interpolated from a standard curve, which was generated using the respective purified or recombinant protein.

ELISAs were first applied to a set of 23 blood samples that included 14 BC patients. If a protein was detected, the ELISA was then performed in the study population $(n=252)$.

\section{Statistical analyses}

Statistical significance was determined with Student's $t$-test (two tailed) comparison between two groups of data sets. A $P$-value $<0.05$ was considered significant. The area under an ROC curve (AUC) is a measure of the overall discriminatory power of the marker (with AUC 1.0 corresponding to perfect prediction and AUC 0.50 corresponding to no discrimination) and was calculated with SPSS software version 15.0 (Chicago, IL, USA).

\section{RESULTS}

\section{Selection of candidate biomarkers for analyses of serum samples}

The process for selection of candidate proteins is reported in Figure 1A. We first identified candidate genes in a data set of exon expression arrays that included $120 \mathrm{BCs}$ and 45 benign lesions (Andre et al, 2009). Gene expression levels were defined as previously described. Of the 72 genes that presented more than a twofold increase in cancer compared with benign lesions, 5 were selected to encode for a protein detectable by ELISA and released in the extracellular medium (Swiss-Prot). These five genes include Fibronectin 1, MIG1 (CXCL9), CFB, Collagen triple helix repeat containing 1 (CTHRC1) and CEACAM5. Figure 1B reports the gene expression levels for these five candidate genes in malignant and benign breast lesions. We then assessed whether these five candidate genes were differentially expressed according to estrogen receptor (ER) expression. Fibronectin 1 and CFB were overexpressed in ER-positive compared with ER-negative disease $(P=0.02$ and 0.004 respectively, $t$-test). Conversely, MIG1 was overexpressed in ER-negative compared with ER-positive disease ( $P=0.05, t$-test; data not shown).

We then assessed the feasibility of ELISA for the five candidate proteins. CEACAM5 was not detectable in the 23 samples tested.
In addition, it was not possible to obtain any signal with recombinant protein (positive control) for CTHRC1, although ELISA provided a signal in some of the 23 samples. For CFB, Fibronectin 1 and CXCL9, standard curve provided a consistent signal and protein was detectable in at least 1 of the 23 samples. As CFB is unstable, only CXCL9 and Fibronectin 1 will therefore be analysed.

\section{Patient characteristics for the serum biomarker study}

The serum biomarker study was performed on 252 samples from either normal volunteers $(n=119)$ or women with non-metastatic breast adenocarcinoma $(n=133)$. Samples were obtained between diagnosis and first treatment for all the patients. Patient characteristics are reported in Table 1 . Briefly, $73 \%$ of the patients presented a cT1-T2 tumour; $34 \%$ and $22 \%$ of the tumours were ER-negative and Her $2+++$ respectively. CA15-3 concentration was assessed in 133 patients. Only $14 \%$ of these patients presented an elevation of CA15-3 ( $\left.\geqslant 30 \mathrm{IU} \mathrm{ml}^{-1}\right)$, suggesting that conventional serum markers could not screen patients in this study population.

\section{Fibronectin 1 serum concentration in cancer patients $v s$ normal volunteers}

Fibronectin 1 concentration was not associated with any clinicopathological characteristics in cancer patients, except age

Table I Patient characteristics

\begin{tabular}{|c|c|}
\hline Characteristics & $n=133(100 \%)$ \\
\hline Median age at diagnosis (range) & $47(32-60)$ \\
\hline \multicolumn{2}{|l|}{ Clinical tumour size } \\
\hline TI & $25(19)$ \\
\hline $\mathrm{T} 2$ & $72(54)$ \\
\hline T3-T4 & $34(25.5)$ \\
\hline Unknown & $2(1.5)$ \\
\hline \multicolumn{2}{|l|}{ Histology } \\
\hline Ductal in situ & $2(1.5)$ \\
\hline Ductal invasive & $101(76)$ \\
\hline Lobular invasive & $12(9)$ \\
\hline Other & $18(13.5)$ \\
\hline \multicolumn{2}{|l|}{ Nodes } \\
\hline 0 & $20(15)$ \\
\hline $1-3$ & $18(13.5)$ \\
\hline$>3$ & $15(11.5)$ \\
\hline Not assessable (preoperative chemotherapy) & $80(60)$ \\
\hline \multicolumn{2}{|l|}{$E R$} \\
\hline Positive & $85(64)$ \\
\hline Negative & $46(34.5)$ \\
\hline Unknown & $2(1.5)$ \\
\hline \multicolumn{2}{|l|}{$P R$} \\
\hline Positive & $70(52.5)$ \\
\hline Negative & $61(46)$ \\
\hline Unknown & $2(1.5)$ \\
\hline \multicolumn{2}{|l|}{ Her-2 neu } \\
\hline Positive & $30(23)$ \\
\hline Negative & $76(57)$ \\
\hline Unknown & $27(20)$ \\
\hline \multicolumn{2}{|l|}{ Histological grade } \\
\hline । & $10(7.5)$ \\
\hline ॥ & $64(48)$ \\
\hline III & $50(37.5)$ \\
\hline Unknown & $9(7)$ \\
\hline
\end{tabular}

Abbreviations: $\mathrm{ER}=$ estrogen receptor; $\mathrm{PR}=$ progesterone receptor. 
$(P<0.001$; Table 2). As reported in Figure 2, the serum concentration of Fibronectin 1 was higher in cancer patients (mean: 190, min: 11, max: $326 \mu \mathrm{g} \mathrm{ml}^{-1}$ ) compared with normal volunteers

Table 2 CXCL9 and Fibronectin I median serum concentrations according to clinical characteristics

\begin{tabular}{|c|c|c|c|c|}
\hline $\begin{array}{l}\text { Characteristics } \\
(n=133)\end{array}$ & $\begin{array}{c}\text { CXCL9 } \\
\left(\mathrm{pg} \mathrm{ml}^{-1}\right)\end{array}$ & $P$ & $\begin{array}{c}\text { Fibronectin I } \\
\left(\mu \mathrm{g} \mathrm{ml}^{-1}\right)\end{array}$ & $P$ \\
\hline \multicolumn{5}{|l|}{ Age } \\
\hline $\begin{array}{l}<35 \\
>35\end{array}$ & $\begin{array}{l}683 \\
788\end{array}$ & 0.27 & $\begin{array}{l}128 \\
177\end{array}$ & $<0.001$ \\
\hline \multicolumn{5}{|l|}{ Clinical tumour size } \\
\hline $\mathrm{TI}$ & 874 & & 206 & \\
\hline $\mathrm{T} 2$ & 791 & 0.69 & 186 & 0.35 \\
\hline T3 & 953 & & 184 & \\
\hline T4 & 1003 & & 199 & \\
\hline \multicolumn{5}{|l|}{ Histology } \\
\hline Ductal in situ & 766 & & 222 & \\
\hline Ductal invasive & 845 & 0.05 & 191 & 0.27 \\
\hline Lobular invasive & 593 & & 187 & \\
\hline \multicolumn{5}{|l|}{ Nodes } \\
\hline 0 & 882 & & 186 & \\
\hline $1-3$ & 762 & 0.35 & 190 & 0.78 \\
\hline $4-9$ & 1044 & & 196 & \\
\hline$>9$ & 711 & & 202 & \\
\hline \multicolumn{5}{|l|}{$E R$} \\
\hline Positive & 773 & 0.07 & 190 & 0.89 \\
\hline Negative & 999 & & 189 & \\
\hline \multicolumn{5}{|l|}{$P R$} \\
\hline Positive & 761 & 0.09 & 192 & 0.54 \\
\hline Negative & 957 & & 187 & \\
\hline \multicolumn{5}{|l|}{ Her-2 neu } \\
\hline Positive & 888 & 0.29 & 186 & $0.7 \mid$ \\
\hline Negative & 741 & & 182 & \\
\hline \multicolumn{5}{|l|}{ Histological grade } \\
\hline I & 728 & 0.21 & 182 & 0.62 \\
\hline$\|$ & 774 & & 187 & \\
\hline III & 998 & & 196 & \\
\hline
\end{tabular}

Abbreviations: $\mathrm{ER}=$ estrogen receptor; $\mathrm{PR}=$ progesterone receptor. (mean: 125, min: 58, max: $\left.212 \mu \mathrm{g} \mathrm{ml}^{-1}\right)(P<0.001)$. Fibronectin 1 concentrations according to cancer status and ER expression are reported in Figure 3.

The metric performances of Fibronectin 1 for $\mathrm{BC}$ diagnosis are reported in Table 3. Area under the curve was 0.77 when a cutoff of 150 was chosen, with a $75 \%$ sensitivity and $80 \%$ specificity. When the analysis focused on ER-negative BC, sensitivity was $72 \%$ and specificity was $79 \%$ (overall accuracy $=77 \%$ ).

When a cutoff of $200 \mu \mathrm{g} \mathrm{ml}^{-1}$ was chosen, the sensitivity and specificity were 43 and $98 \%$, respectively. Using this cutoff, the positive predictive value was $97 \%$.

\section{CXCL9 serum concentration in cancer patients vs normal volunteers}

The CXCL9 serum concentrations according to clinical characteristics are reported in Table 2. The average CXCL9 serum concentrations were 999 and 773 in patients with ER-negative and -positive disease $(P=0.07, t$-test), data consistent with gene expression data. As reported in Figure 2, the serum concentration of CXCL9 was higher in cancer patients (mean: 851, min: 121, max: $3941 \mathrm{pg} \mathrm{ml}^{-1}$ ) compared with normal volunteers (mean: 635, min: 12, max: $\left.4327 \mathrm{pg} \mathrm{ml}^{-1}\right)(P=0.013)$. When the analyses focused on ER-negative disease, the difference between BC samples (mean concentration: 999) and normal volunteers (mean concentration: $635)$ was statistically significant $(P=0.003, t$-test $)$. At the opposite end, CXCL9 concentrations were not different between ER-positive BC (mean concentration: 773) and normal volunteers (mean concentration: 635$)(P=0.14)$. CXCL9 concentrations according to cancer status and ER expression are reported in Figure 3.

The metric performances of CXCL9 for BC diagnosis are reported in Table 3. Area under the curve was 0.624 when a cutoff of $750 \mathrm{pg} \mathrm{ml}^{-1}$ was chosen, with a sensitivity of $45 \%$ and specificity of $79 \%$. When the analyses focused on ER-negative disease, using the same cutoff at $750 \mathrm{pg} \mathrm{ml}^{-1}$, sensitivity and specificity were 57 and $80 \%$ respectively. Overall accuracy was $73 \%$ for the detection of ER-negative BC.

When a cutoff of $1000 \mathrm{pg} \mathrm{ml}^{-1}$ was chosen, sensitivity was $27 \%$ and specificity was $90 \%$. Using this cutoff, the positive predictive value was $76 \%$.

\section{Combined detection of FN1 and CXCL9 for breast cancer detection}

As stated in the beginning, the objective of serum marker for $\mathrm{BC}$ screening would be to increase the performance of a mammogram.
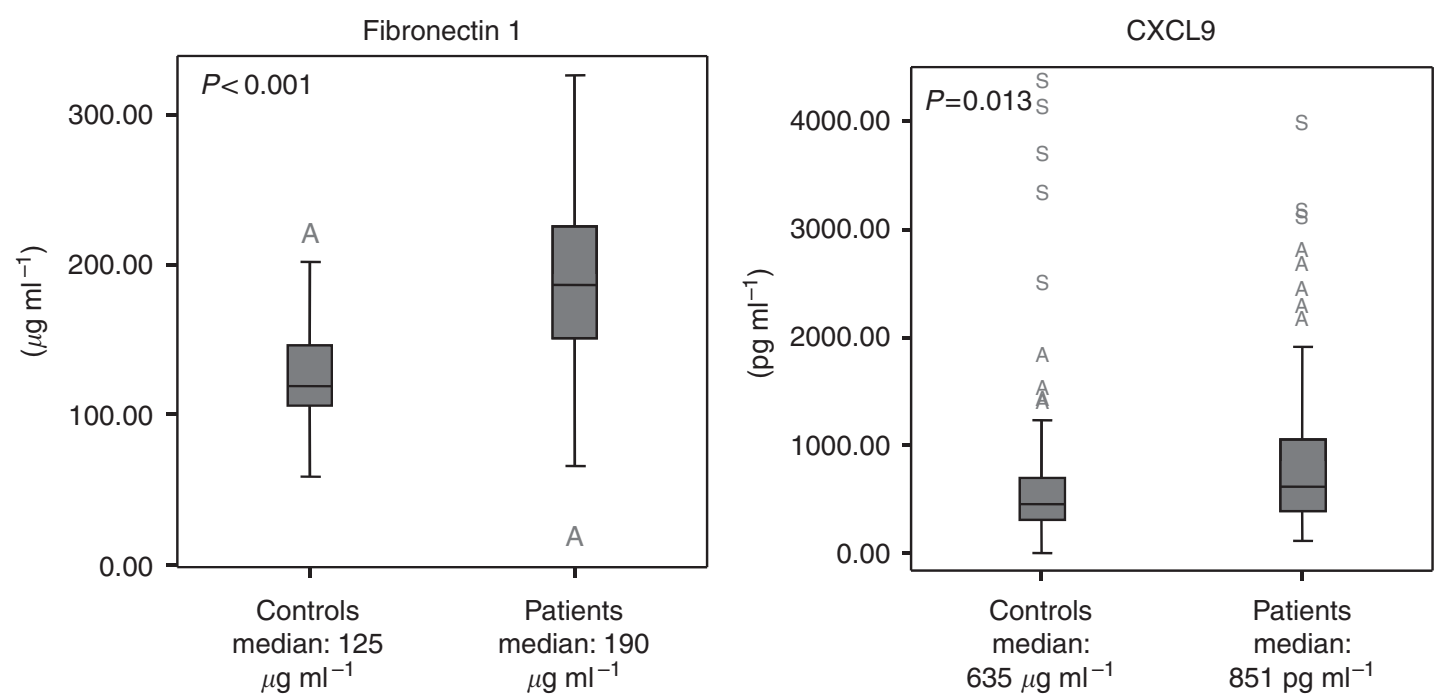

Figure 2 Serum concentration of CXCL9 and Fibronectin I in cancer vs normal volunteers. 

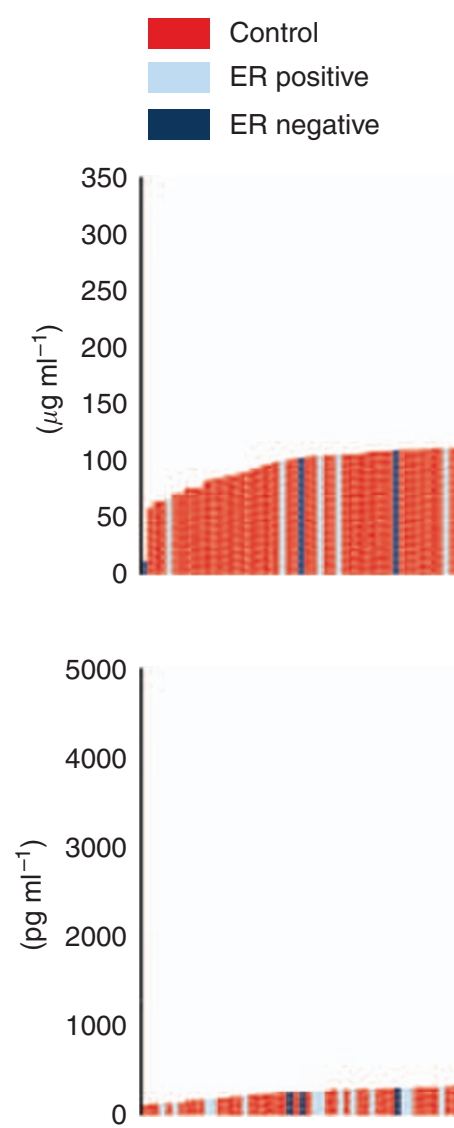

Fibronectin 1

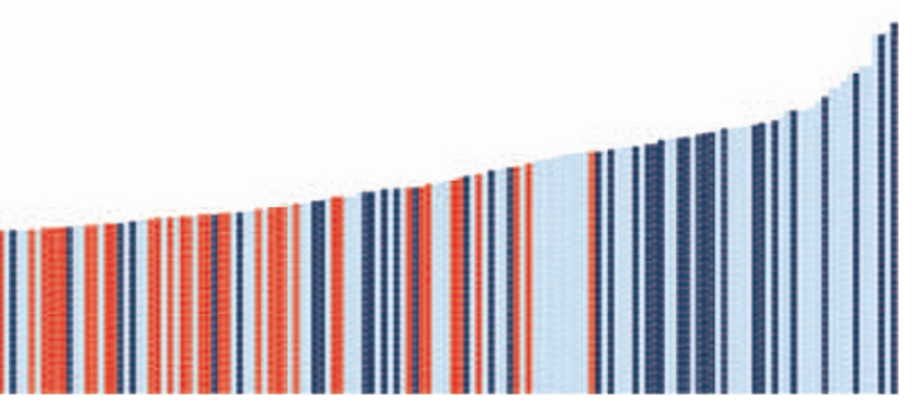

CXCL9

Figure $3 \mathrm{CXCL9}$ and Fibronectin I serum concentrations according to cancer status and ER expression.

Table 3 Metric performance of Fibronectin I and CXCL9 dosages for BC diagnosis

\begin{tabular}{|c|c|c|c|c|c|c|c|c|}
\hline & $\begin{array}{l}\text { Sensitivity } \\
(\%)\end{array}$ & $\begin{array}{l}\text { Specificity } \\
(\%)\end{array}$ & $\begin{array}{c}\text { Positive predictive } \\
\text { value (\%) }\end{array}$ & $\begin{array}{c}\text { Negative predictive } \\
\text { value (\%) }\end{array}$ & $\begin{array}{l}\text { Accuracy } \\
(\%)\end{array}$ & AUC & $95 \% \mathrm{Cl}$ & $P$ \\
\hline MIG $750 \mu \mathrm{g} \mathrm{ml} l^{-1}$ & 45 & 79 & 71 & 56 & 73 & 0.624 & $0.55-0.69$ & 0.001 \\
\hline MIG $1000 \mu \mathrm{g} \mathrm{ml}^{-1}$ & 28 & 90 & 76 & 52 & 57 & 0.588 & $0.5 I-0.65$ & 0.016 \\
\hline FNI $200 \mathrm{pg} \mathrm{ml}^{-1}$ & 42 & 98 & 97 & 60 & 41 & 0.706 & $0.64-0.70$ & $<0.001$ \\
\hline
\end{tabular}

Abbreviation: $A \cup C=$ area under the curve.

Overall, the screening test is expected to be a combination between a serum marker and a mammogram. The goal would be to detect an optimal rate of BC (including ER-negative BC) while keeping a maximal positive predictive value and specificity to avoid unnecessary exams for false-positive results. We considered cases with Fibronectin $1<150 \mathrm{pg} \mathrm{ml}^{-1}$ as negative and those with Fibronectin $1>200 \mathrm{pg} \mathrm{ml}^{-1}$ as positive. For intermediate concentrations $\left(150<\right.$ Fibronectin $\left.1>200 \mathrm{pg} \mathrm{ml}^{-1}\right)$, patients with CXCL9 concentrations $>1000 \mathrm{pg} \mathrm{ml}^{-1}$ were considered as positive, and those with CXCL9 $<1000 \mathrm{pg} \mathrm{ml}^{-1}$ were considered as negative. Using this algorithm, we found that 73 and 177 cases were positive and negative respectively. The sensitivity to detect cancer was $53 \%$ and specificity was $97 \%$. The positive predictive value was $96 \%$. This score allowed detection in 25 out of 46 ER-negative BCs (54\%).

\section{DISCUSSION}

In this study, we have reported that CXCL9 and Fibronectin 1 serum concentrations are higher in $\mathrm{BC}$ patients compared with normal volunteers. CXCL9 is an interferon-induced chemokine, involved in T-cell attraction (Liao et al, 1995; Gasperini et al, 1999). Several studies have shown that CXCL9 is released by cancer cells, including melanoma (Kunz et al, 1999) or renal cancer cell (Bukowski et al, 1999). Fibronectin 1 is a glycoprotein involved in cell-matrix and cell-cell adhesion, cell migration and oncogene transformation (Gould et al, 1990), as well as in tumour invasion and metastasis (Yamada et al, 1985; Schwartzbauer, 1988; Humphries and Yasuda, 1988; Couchman et al, 1990).

The two proteins, Fibronectin 1 and CXCL9, were identified by the analysis of differentially expressed genes between malignant and benign lesions of the breast. This strategy could be extended for other frequent tumour types, including lung cancer (Humphries and Yasuda, 1988), for which new screening tools are needed. Optimal BC screening is expected to decrease tumour size and lymph node involvement at diagnosis. Unfortunately, BC screening by mammogram misses a significant rate of $\mathrm{BC}$ (interval cancer) and is associated with a high rate of false-positive results, requiring unnecessary biopsies. This latter point is particularly true for new 
technologies including MRI. With the current cutoff, the present serum marker exhibits average sensitivity but high specificity and positive predictive value. When combined with a mammogram, this test is expected to improve the detection of $\mathrm{BC}$ modestly. The resulting performance will be an increased sensitivity for the screening test. If developed in combination with a mammogram, it is important for the test to present a high specificity to avoid additional false-positive results to the ones of mammogram. Also, with a high specificity biopsy could be avoided and surgery be performed in patients with ACR4/5 lesion who present a positive serum screening. Finally, adding a serum test with high negative predictive value to mammogram could also improve patient care by avoiding unnecessary biopsy in patients with ACR4 mammograms. This test presents only modest negative predictive values and will not avoid biopsies in these latter patients.

Integration of the Fibronectin 1/CXCL9 score in a screening and post-screening programme could allow both to increase the rate of detected cases and to decrease the rate of unnecessary biopsies. The Fibronectin 1/CXCL9 score looks particularly interesting to detect ER-negative BCs (54\% detection). Mass screening is associated with poor detection of these aggressive BCs. In a recent study (Yang et al, 2008), it was suggested that for triple-negative $\mathrm{BC}$, mammogram may not be the ideal imaging technique. This is related to both the radiological (lack of microcalcification, occurrence in high-density BC) and the biological (high proliferation rates) features of such cancers. The present data suggest that Fibronectin 1/CXCL9 score could allow to screen a significant rate of patients with ER-negative BC.

Several studies have evaluated the use of serum biomarkers for BC care. None of these studies could identify a robust marker for BC screening. Some studies have shown that although preoperative CA15-3 has a prognostic relevance (Shering et al, 1998), others do not (Ebeling et al, 2002). Some data support that $\mathrm{CEA}$ is a strong independent prognostic factor for disease-free

\section{REFERENCES}

Andre F, Michiels S, Dessen P, Scott V, Suciu V, Uzan C, Lazar V, Lacroix L, Vassal G, Spielmann M, Vielh P, Delaloge S (2009) Exonic expression profile of breast tumors: a retrospective analysis of 165 samples from patients referred to a diagnosis center. Lancet Oncol 10(4): $381-390$

Bartsch R, Wenzel C, Pluschnig U, Hussian D, Sevelda U, Altorjai G, Locker GJ, Mader R, Zielinski CC, Steger GG (2006) Prognostic value of monitoring tumour markers CA 15-3 and CEA during fulvestrant treatment. BMC Cancer 6: 81

Bukowski RM, Rayman P, Molto L, Tannenbaum CS, Olencki T, Peereboom D, Tubbs R, McLain D, Budd GT, Griffin T, Novick A, Hamilton TA, Finke J (1999) Interferon-gamma and CXC chemokine induction by interleukin 12 in renal cell carcinoma. Clin Cancer Res 5(10): 2780-2789 Couchman JR, Austria MR, Woods A (1990) Fibronectin-cell interaction. J Invest Dermatol 94: $7 \mathrm{~s}-14 \mathrm{~s}$

Davis MA, Hanash S (2006) High-throughput genomic technology in research and clinical management of breast cancer. Plasma-based proteomics in early detection and therapy. Breast Cancer Res 8(6): 217

Delaloge S, Rouzier R, Balleyguier C, Andre F, Vanel D, Mathieu MC, Garbay JR, Derneville AM, Marsiglia H, Spielmann M, Vielh P (2005) A nomogram to predict for malignant diagnosis of solid lesions in a onestop breast unit. San Antonio Breast Cancer Symposium. Breast Cancer Res Treat 94(Suppl 1): 2024

Ebeling FG, Stieber P, Untch M, Nagel D, Konecny GE, Schmitt UM, FatehMoghadam A, Seidel D (2002) Serum CEA and CA 15-3 as prognostic factors in primary breast cancer. Br J Cancer 86: 1217-1222

Fletcher SW, Elmore JG (2003) Clinical practice: mammographic screening for breast cancer. $N$ Engl J Med 348(17): $1672-1680$

Gasperini S, Marchi M, Calzetti F, Laudanna C, Vicentini L, Olsen H, Murphy M, Liao F, Farber J, Cassatella MA (1999) Gene expression and production of the monokine induced by IFN-g (MIG), IFN-inducible survival and death from disease (Ebeling et al, 2002). Also, these two markers have been studied in the monitoring of treatment efficacy; however, both were related to be poor prognostic markers for determining progression (Bartsch et al, 2006).

Some bioassays have been set up with the aim of screening BC patients. Several reports (Tamkovich et al, 2005; Huang et al, 2006) have suggested that the concentration of tumoural DNA was higher in the serum of $\mathrm{BC}$ patients compared with healthy volunteers. Proteomics is another promising technology for BC screening and diagnosis (Davis and Hanash, 2006). Nevertheless, none of these bioassays has shown enough performance to be transferred onto clinical practice.

Although this study reports two candidate proteins that could screen a significant rate of patients with $\mathrm{BC}$, it presents several limitations. First, no validation set has been included in the analysis. A prospective clinical study is ongoing that will better assess the metric performance of the bioassay. Second, the population of normal volunteers included blood donors who are selected for not presenting any symptom or acute disease. Further validation will need to select negative controls carefully. Finally, the sensitivity of the test needs improvements. Additional proteins will be included in the bioassay. These proteins have been selected to be encoded by genes overexpressed in BC, but for which no ELISA was feasible.

In conclusion, analysis of differential gene expression between cancer and normal tissue allows the identification of candidate proteins for blood-based cancer screening.

\section{ACKNOWLEDGEMENTS}

This study was funded by 300 donors in the 'operation parrain chercheur'. E Ruiz was funded by EGIDE.
T cell-chemoattractant (I-TAC), and IFN-g inducible protein-10 (IP-10) chemokines by human neutrophils. I Immunol 162: 4928-4937

Gould VE, Koukoulis GK, Virtanen I (1990) Extracellular matrix proteins and their receptors in the normal hyperplastic and neoplastic breast. Cell Diff Dev 32: 409-416

Hakama M, Coleman MP, Alexe DM, Auvinen A (2008) Cancer screening: evidence and practice in Europe 2008. Eur J Cancer 44: 1404- 1413

Harris L, Fritsche H, Mennel R, Norton L, Ravdin P, Taube S, Somerfield MR, Hayes DF, Bast Jr RC (2007) American Society of Clinical Oncology 2007 update of recommendations for the use of tumor markers in breast cancer. J Clin Oncol 25: 5287-5312

Huang ZH, Li LH, Hua D (2006) Quantitative analysis of plasma circulating DNA at diagnosis and during follow-up of breast cancer patients. Cancer Lett 243(1): $64-70$

Humphries MJ, Yasuda Y (1988) The cell interaction sites of fibronectin in tumor metastasis. Ciba Found Symp 141: 75-93

Karim-Kos HE, de Vries E, Soerjomataram I, Lemmens V, Siesling S, Coebergh JW (2008) Recent trends of cancer in Europe: a combined approach of incidence, survival and mortality for 17 cancer sites since the 1990s. Eur J Cancer 44: 1345-1389

Kunz M, Toksoy A, Goebeler M, Engelhardt E, Bröcker E, Gillitzer R (1999) Strong expression of the lymphoattractant C-X-C chemokine Mig is associated with heavy infiltration of $\mathrm{T}$ cells in human malignant melanoma. J Pathol 189(4): 552-558

La situation du cancer en France I. N. (s.f.). www.e-cancer.fr

Liao F, Rabin RL, Yannelli JR, Koniaris LG, Vanguri P, Farber JM (1995) Human Mig chemokine: biochemical and functional characterization. J Exp Med 182: $1301-1314$

Nystrom L, Andersson I, Bjurstam N, Frisell J, Nordenskjöld B, Rutqvist LE (2002) Long-term effects of mammography screening: updated overview of the Swedish randomised trials. Lancet 359(9310): 909-919 
Schwartzbauer J (1988) Fibronectin: from gene to protein. Curr Opin Cell Biol 3: $781-786$

Shering SG, Sherry F, McDermott EW, O’Higgins NJ, Duffy MJ (1998) Preoperative CA 15-3 concentrations predict outcome of patients with breast carcinoma. Cancer 83: 2521-2527

Tamkovich SN, Laktionov PP, Rykova EY, Starikov AV, Skvortsova TE, Kuznetsova NP, Permyakova VI, Vlasov VV (2005) Plasma content of extracellular nucleic acids in donors and patients with mammary tumors. Bull Exp Biol Med 139: 465-467

Yamada KM, Akiyama SK, Hasegawa T, Hasegawa E, Humphries MJ, Kennedy DW, Nagata K, Urushihara H, Olden K, Chen WT (1985) Recent advances on research of fibronectin and other cell attachment proteins. J Cell Biochem 28: 78-79

Yang WT, Dryden M, Broglio K, Gilcrease M, Dawood S, Dempsey PJ, Valero V, Hortobagyi G, Atchley D, Arun B (2008) Mammographic features of triple receptor-negative primary breast cancers in young premenopausal women. Breast Cancer Res Treat 111(3): $405-410$ 